\title{
The instrument for determining the views of primary school students about historical knowledge*
}

\author{
Banu ÇULHA ÖZBAŞ ${ }^{* *}$ Erdal ASLAN ${ }^{* * *}$
}

\begin{abstract}
The purpose of this research is to develop a reliable and valid instrument in order to determine the primary school students' view about historical knowledge. A total of 525 students of $6^{\text {th }}, 7^{\text {th }}$ and $8^{\text {th }}$ grades from 6 different primary schools were participated in this study. The instrument is composed of totally 20 items with five factors namely, certainty of historical knowledge (5 items), the source of historical knowledge (4 items), the development of historical knowledge (4 items), the basis of historical knowledge (4 items), the transference of historical knowledge (3 items), and the whole instrument has a reliability coefficient of Cronbach $\alpha=0.82$. At the same time, this instrument is also the first original instrument developed for determining the primary school students' view about historical knowledge in Turkey.
\end{abstract}

Keywords: Views about historical knowledge, epistemic cognition, primary students, social studies and elementary history education.

\footnotetext{
* This article is based on the first author's doctoral dissertation in Teaching History, which was completed at the Dokuz Eylül University under the direction of the second author.

** Ph.D., Dokuz Eylül University, Buca Faculty of Education, Department of Primary Education, Social Studies Education, İzmir, Turkey. E-mail: banu.culha@deu.edu.tr.

*** Asst. Prof., Dokuz Eylül University, Buca Faculty of Education, Department of Social Sciences, History Teaching, İzmir, Turkey.
} 


\section{SUMMARY}

Purpose and Significance: The teaching of history should be concerned with developing children's understanding of what history is. But if we do not know how students think or which ideas they have about the nature of history, we cannot be effective in promoting their conceptual change. Therefore, it is important to identify the views of the students about historical knowledge. However, there has not been such an instrument developed toward the understanding of the primary students' views of the historical knowledge in Turkey up today. The main starting point of this study is the absence of such an instrument towards Turkish primary students. Thus our aim in this study is to develop a valid and reliable instrument about the historical knowledge understandings of primary students.

Method: The study was conducted with 525 students attending to $6^{\text {th }}$, $7^{\text {th }}$, and $8^{\text {th }}$ grades of the primary schools located in Buca, İzmir chosen by stratified sampling. The instrument development studies were composed of the preparation of the items, having expert views about the items for the scope validity, pilot study, the analysis of construct validity and reliability. The analysis showed the instrument has 5 Factors: certainty of historical knowledge (5 items), the source of historical knowledge (4 items), the development of historical knowledge (4 items), the basis of historical knowledge (4 items), and the transference of historical knowledge (3 items). The reliability of the instrument was found to be 0,82 .

Results: The results showed that the instrument developed is valid and reliable $(\alpha=0,82)$. Meanwhile, it is the first instrument developed for determining the historical knowledge of the primary students in Turkey.

Conclusions: The developed instrument can be used by both researchers and the social studies teachers. 


\title{
İlköğretim Öğrencilerinin Tarihsel Bilgiye Yönelik Görüş̧lerini Belirleme Ölçeği
}

\author{
Banu ÇULHA ÖZBAŞ ${ }^{* *}$ Erdal ASLAN ***
}

ÖZ. $\mathrm{Bu}$ çalışmanın amacı, ilköğretim öğrencilerinin tarihsel bilgiye yönelik görüşlerini belirlemek amacıyla geçerli ve güvenilir bir ölçek geliştirmektir. Araştırmaya 6 ilköğretim okulunun 6., 7., 8., sınıflarında öğrenim görmekte olan toplam 525 öğrenci katılmıştır. Ölçek geliştirme çalışmaları sonucunda ölçeğin Tarihsel Bilginin Kesinliği (5 madde), Tarihsel Bilginin Kaynağı (4 madde), Tarihsel Bilginin Gelişimi (4 madde), Tarihsel Bilginin Dayanağı (4 madde), Tarihsel Bilginin Aktarımı (3 madde) olmak üzere toplam beş faktör ve 20 maddeden oluştuğu ve ölçeğin tamamının Cronbach $\alpha$ güvenilirlik katsayısının ise 0.82 olduğu belirlenmiştir. Ölçek aynı zamanda, ilköğretim öğrencilerinin tarihsel bilgiye yönelik görüşlerini belirlemek üzere Türkiye'de geliştirilen özgün ilk ölçek olma niteliği taşımaktadır.

Anahtar Sözcükler: Tarihsel bilgiye yönelik görüş, epistemolojik görüş, ilköğretimde sosyal bilgiler ve tarih öğretimi.

\footnotetext{
* Makale birinci yazarın ikinci yazar danışmanlığında, Dokuz Eylül Üniversitesi’nde Tarih Eğitimi alanında tamamladığ 1 doktora tezine dayanmaktadır.

** Dr., Dokuz Eylül Üniversitesi Buca Eğitin Fakültesi İlköğretim Bölümü Sosyal Bilgiler Eğitimi İzmir, Türkiye. E-posta: banu.culha@deu.edu.tr.

Yrd. Doç. Dr., Dokuz Eylül Üniversitesi Buca Eğitin Fakültesi Ortaöğretim Bölümü Tarih Eğitimi İzmir, Türkiye.
} 


\section{GÍRIŞ}

Tarih ne sadece geçmişin hikâyesi ne de uzun zaman önce meydana gelmiş olayların kayıt altına alınmasıdır. Özbaran'a (1992) göre tarih, geniş anlamıyla geçmişte insanların yaptıklarına, beklentilerine veya niyetlerine ve çelişkilerine ilişkin olarak gerçekliğine inanılarak ortaya konulmuş betimlemelerdir. Carr (1996) ise tarihi, tarihçi ile olaylar arasında sürekli bir iletişim, günümüz ile geçmiş arasında bitmeyen bir diyalog olarak tanımlamaktadır. Dilek ise tarihi, zaman ve boşlukta geçmişe yapılan bir seyahat, geçmişten gelen deneyimleri yansitma gücüne sahip bir disiplin olarak tanımlamaktadır (Dilek, 2002:6). Tüm bu tanımlardan yola çıkarak söyleyebileceğimiz, günümüzde tarihin yer ve zaman göstererek olaylar1 kronolojik sıraya koyma etkinliği olmadığıdır. Bu çerçevede tarihi, bir bilgi yığını olmaktan kurtarmak, Breisach'in (2009: 16) ifadeleri ile onu, bir torba dolusu kuru yaprağı karıştırıp taramaya benzer aylak bir uğraş olmaktan çıkararak insan hayatı için elzem bir etkinlik haline getirmek gerekmektedir. Levstik ve Barton (2001) bugün artık okul programlarında tarihin, öğrencilerin kendi yaşamlarını anlamlandırmalarına yardımcı olan araştırma süreçlerini öğrenebilecekleri bir ders olarak bulunması gerektiği üzerinde durmakta, Foster ve Yeager (1999) ise öğrencilerin kaynakların güvenilirliğini ve geçerliliğini sorgulayabildikleri, geçmişte yaşayan insanlarla, olaylarla, fikirlerle ilgili değerlendirmeleri yapabildikleri bir disiplin olması gerektiğini savunmaktadır. Levstik ve Barton (2001) okul programında tarihin özel bir yeri olduğunu, bu yerin de çocukların kendi dünyaları ile ulusal tarih arasında bir bağ kurmalarını sağlayan, yani çocukların "Ben kimim?", "Nereden geldim ve nereye gidiyorum?", "Biz kimiz?", "Nereden geldik ve nereye gidiyoruz?" gibi sorularına cevap verebilecek bir ders olmasında yattığını söylemektedir. Gerçekten de her insan doğal olarak yaşadığ 1 toplumun bugüne nasıl geldiğini merak eder ve kafasında konuya ilişkin ne kadar yarım yamalak ve yanlış temellendirilmiş olursa olsun bir takım/bazı açıklama vardır (Tosh, 2005:3-4).

Günümüzde tarihçilik ve tarih eğitimine yönelik araştırmaların bulgularına paralel biçimde okullardaki tarih çalışması da, geçmişteki olayları olduğu gibi öğrenme amacının ötesine geçerek, geçmiş hakkındaki bilginin nasıl elde edilebileceği üzerinde odaklanmıştır (Yapıcı, 2006:26). Böyle bir tarih öğretimi yaklaşımı ise kaçınılmaz şekilde, tarihsel kaynaklarla çalışma, tarihsel sorgulama ve tarihsel düşünme becerilerine gereksinim duyar ve geçmişi, bir tarihçi gibi yeniden kurma edimi, tarihsel düşünme/anlama/imgelem süreçlerinin deneyimlenmesi ve geliştirilmesi ile mümkün olabilir (Dilek 2009:636). Dilek'in bu açıklamaları tarih eğitimcilerinin son otuz yıldır üzerinde durdukları "tarihsel düşünme" kavramının da merkezini oluşturmaktadır. Kısaca; tarihsel düşünmeden 
kastedilen ders kitaplarındaki bilgileri ezberlemek değil, öğrenciye tarihin bir disiplin olarak kendisine özgü düşünme becerilerini kazandırmaktır (Barton, 1996; Seixan, 1996 ve VanSledright, 2002). Öğrencilerin tarihi bir sosyal disiplin olarak görmeleri esastır. Çünkü tarih, disiplin olarak anlattığg hikâyelerden çok daha önemlidir (Lee, 2000). Jenkins'e (1997:31) göre de tarih, okul ve akademik ders programları içinde bir yer olmaktan çok daha fazla bir şeydir. Öğrenciler okulda sadece tarihsel bilgi ile karşı̧laşmazlar; aynı zamanda tarihin ne olduğu, tarihsel bilginin nasıl yazıldı $\breve{1}$, tarihsel bilginin kaynağının ne olduğuna ilişkin fikirler de edinirler (Çulha, 2006) ve bu görüşler öğrencilerin tarih öğrenmelerini etkiler. Öğrencilerin tarihsel bilgiye yönelik görüşlerini bilmek ise çok önemlidir, çünkü ancak bu yolla onların Sosyal Bilgiler dersinde karşılaştıkları tarihi nasıl algıladıkları anlaşllabilir. Fakat Türkiye'de ilköğretim öğrencilerinin tarihsel bilgiye yönelik görüşlerini ölçmeye yarayacak ve geniş örneklem gruplarına uygulanarak çeşitli değişkenler açısından çoklu değerlendirmelere gidilebilecek bir ölçek bulunmamaktadır. Bu nedenle araştırmamızın amacı ilköğretim öğrencilerinin tarihsel bilgiye yönelik görüşlerinin (tarihsel bilginin kaynağı, aktarımı, gelişimi, dayanağı, kesinliği) neler olduğunu ölçmek için geçerli ve güvenilirliği olan bir ölçek geliştirmek ve bu ölçeğin geliştirilme safhalarını paylaşmaktır. Bunun için öncelikle Tarihsel Bilgiye Yönelik Görüş Ölçeğinin teorik yapısı üzerinde durulacak, ardından ölçek maddelerinin hazırlanması, kapsam geçerliliğinin sağlanması, güvenilirliği gibi ölçek geliştirme safhaları verilecek ve sonuç bölümünde de ölçekle ilgili genel bir değerlendirme yapılacaktır.

\section{İlköğretim Öğrencilerinin Tarihsel Bilgiye Yönelik Görüşleri Ölçeğinin Teorik Yapısı}

İlköğretim öğrencilerinin tarihsel bilgiye yönelik görüşlerini incelemek için geliştirilen bu çalışmanın ölçek maddeleri hazırlanırken, öncelikle üç araştırma alanındaki bilgilerden yararlanılmıştır. Bunlardan ilki genelde bilginin kaynağını, doğasını, doğruluğunu ve sınırlarını inceleyen (Cevizci, 1997:248) felsefenin epistemoloji alanıdır ki, bu çalışma özelinde tarih epistemolojisi alanıdır (Collingwod 2000; Özden 2005). İkincisi insanlarda genel olarak epistemolojik bilişi (epistemic cognition) konu alan çalışmalardır (King ve Kitchener 2002; Kuhn ve Weinstock 2002; Schommer 1990). Üçüncü olarak da tarihsel düşünmenin gelişimini konu alan çalışmalardan yararlanılmıştır (Lee 2004; Stearns, Seixas ve Wineburg 2000; Wineburg 2001). Son iki alanda bireysel derinlemesine görüşmeler yapılarak veri toplanmış ve bu yüzden de ölçek maddelerinin hazırlanmasında ilgili araştırma sonuçlarından oldukça istifade edilmiştir. 
King ve Kitchener tarafından geliştirilen Yansıtıcı Değerlendirme Modeli (Reflective Judgment Model - RJM - YDM) Dewey'nin yansitic1 düşünme tanımından yola çıkılarak oluşturulmuştur. $\mathrm{Bu}$ araştırma sonucunda yansitma öncesi (prereflective), yarı yansitıc1 (quasi-reflective) ve yansıtma (reflective) olmak üzere üç aşama belirlenmiştir. Kuhn ve Weinstock (2002) ise araştırmalarında, bireylerin bilgi ile dış gerçeklik arasındaki ilişkiyi anlamalarının nasıl değiştiğine odaklanmış ve Epistemolojik Anlama Düzelerine (Levels of Epistemological Understanding - LEU- EAD ) ilişkin 4 farklı aşama belirlemişlerdir. Bunlar: realist (gerçekçi), mutlakçı (absolutist), çoklu bakışlı (multiplist) ve değerlendirmecidir (evaluativist).

Burada teorik yapı olarak yansıtma ile ilgili çalışmalardan yararlanılmasının sebebi, tarihçilerin de tarihsel bilgiye ulaşırken tarihsel kanıtları değerlendirme sürecinde aslında bu modele benzer bir süreç izlemeleridir. Örneğin, yansıtma öncesi dönemde bireyler iyi yapılandırılmamış araştırma problemlerinin, sonuçları olumsuz etkileyebileceğinin farklında değildir. Benzer bir biçimde gerçekçi aşamada olan bireylerin de iddiaların dış gerçekliğin bir kopyası olduğu inancında oldukları bilinmektedir. Yansıtma öncesi dönemin diğer bir özelliği ise doğru ve yanlış bilgiyi birbirinden ayırmanın her zaman mümkün olduğu kanısıdır. Buna göre iyi otoriteler her zaman doğru cevabı bilebilirler. Benzer olarak mutlakıyetçi aşamada da bireyler yanlış inançların olabileceğini düşünürler ve iddiaların gerçeklerden temellendiğini bilirler. Fakat gerçekliği sunmada doğru ya da yanlış davranabilirler. Bu sebeple bilgiler, bireylerin bireysel düşüncelerinde temellenir. Bu, RJM'nin (YDM) yansıtma öncesi dönemi ile aynıdır. Çok bakışlı aşamada (LEU-EAD) bilme süreci olarak konunun önemi daha önemli görülür. Bilmenin objektif hali geri çekilir; iddialar burada fikirler, kendi sahipleri tarafından özgürce seçilen bilgiler olarak anlaşılmaya başlanır (Kuhn ve Weinstick, 2002:124). RJM'de (YDM) buna benzer öznel ve bilgiye kavramsal yaklaşım yarı yansıtmacılık olarak karşımıza çıkar. Bu aşamadaki bireyler için bilgisel iddialar tam bir kesinlik içermez; bazen araştırmada metodolojik ya da kanıtların doğasından veya yanlış kullanımlarından kaynaklı problemler yaşanabilir. Her ne kadar RJM (YDM) kanıtsal izler üzerine odaklansa da bu bir seçimdir ve özel durumlarla ilgili tartışmalar da yapılabilir. Son olarak, yansıtmacı uslamlama/akılyürütme RJM'de (YDM) üçüncü dönem olarak tanımlanır. Doğrulama ve değerlendirme elde olan kanitlara dayandırılmalıdır. Eğer yeni kanıtlar ya da yeni metotlar uygulanırsa bilgilerin değişebileceği gösterilmektedir. Buna benzer bir durum, değerlendirme aşaması olarak LEU'da $(E A B)$ da görülür. Bilgiye yönelik yanlı ve yansız yaklaşımlar değerlendirmeyi etkiler ve iddialar birer hüküm 
olarak değerlendirilir. $\mathrm{Bu}$ değerlendirme ve karşılaştırma iddialar ve kanitlarla ilgilidir (Kuhn ve Weinstock, 2002:124).

$\mathrm{Bu}$ araştırmalar öğrencilerin tarihsel bilgiye yönelik görüşlerini inceleyen alan araştırmaları ile de paralellik göstermektedir; örneğin tarihçiler ve parlak lise tarih ögrencilerinin tarihsel bilgiye yönelik görüşlerini inceleyen (Wineburg, 1991) ya da tarih öğretmenlerinin (Yeager ve Davis, 1996) tarihsel bilgiye yönelik görüşlerini inceleyen araştırmalar gibi. Fakat bu araştırmada özellikle İngiltere'deki 7-14 yaş arasında derinlemesine bir çalışma gerçekleştiren Lee ve Ashby'nin çalışmasından yararlanılmıştır. Ayrıca Lee ve Shemilt (2003) de öğrencilerin kanıtlara ilişkin fikirlerini 6 aşamada incelenebileceğini ortaya koymuşlardır. Birinci aşamada Lee ve Shemilt, öğrencilerin kanttları geçmişe doğrudan ulaşma aracı olarak değerlendirdiklerini ortaya koymuştur. İkinci aşamada öğrenciler kanıtları bilgi kaynağı olarak ve tarihi de bazı otoriteler tarafindan kesin olarak bilinebilecek bilgiler bütünü olarak görmektedir. Burada, öğrencilerin tarih ile geçmiş arasındaki ayrımı henüz fark etmedikleri görülür. Öğrenciler tarihin sadece geçmişin yansıması olduğunu düşünürler. Öğrencilerin bu seviyelerde, kanıtları geçmişin bir kopyası olarak gördükleri söylenebilir. Bu aynı zamanda RJM açısından yansıtma öncesi dönem, LEU (EAB) açısından da realist ya da mutlakıyetçi dönem olarak değerlendirilebilir. Lee ve Shemilt (2003)'e göre gelişim, üçüncü ve dördüncü aşamalarda başlar. Öğrenciler bu aşamada tarihsel çıkarımların doğruluğunu sorgulamaya başlar ve tarihçilerin tarihi, kanıtlardaki en iyi bilgileri bir araya getirerek oluşturduklarını düşünürler. Farklı kanıtlar içindeki en inandırıcı parçaların tarihçiler tarafından bir araya getirilerek tarihin yazıldığı düşünülür. Bu aşamada öğrenciler ödünç alıcılar (borrower) olarak değerlendirilmektedir. Öğrenciler bu aşamada hala tarihsel kaynakları kanıtlara çevirmekte nasıl bir yol izleyeceklerini bilmemektedir. Hala otorite kaynaklar önemlidir ve öğrenciler için birbiri ile çelişen kaynaklar rahatsız edicidir. Bu aşama RJM'de (YDM) yarı yansıtma ya da LEU'da (AEB) çoklu bakışlı olarak değerlendirilebilir. Lee ve Shemilt (2003) tarafindan belirlenen beşinci ve altıncı aşamalarda öğrenciler, tarih araştırmacısının duruşunun öneminin farkındadır. Öğrenciler, sorulara cevap vermek için geliştirilmeyen kanıtlara yönelik sorular soran tarihçilerin soru sormadaki rolünden haberdardır. $\mathrm{Bu}$ aşamalarda öğrenciler kaynağ 1 bırakanın bakış açısı ve farklı kaynaklarda çelişen bilgilerin değerlendirilmesi gerektiğinin ve tarih araştırmacısının kaynaklardaki eksiklikleri gidermedeki rolünün farkındadırlar. Burada artık tarih araştırması yine ve yeniden yapılabilinir olarak görülmeye başlanmıştır. $\mathrm{Bu}$ aşama değerlendirmeci (criterialist/evaluativist) olarak tanımlanabilir. 
$\mathrm{Bu}$ açıklamalardan anlaşılabileceği gibi yansıtma öncesi döneme ait bir özellik, LEU'da (EAB) gerçekçi ve mutlakıyetçi aşamaya ait bir özellik olarak da bulunabilir. Tarihte ise buna benzer bir bakış kopyacı tutum olarak değerlendirilebilir. Burada tarihin kanıtlara ihtiyacı yoktur. Benzer olarak, yarı yansıtmacı aşamada da çok yönlü dönem, LEU'da (EAD) kesin olmayan dönemdir. Tarihte ise buna paralel görüşler "tarihte gerçekten ne olduğunu kimse bilemez; tarihsel bilginin güvenilirliğini arttıran şey tarihsel olayın görgü tanıkları tarafindan aktarılıp aktarılmamasıdır" şeklinde örneklendirilebilir. Yansıtmacı düşünmede ise öğrencilerin kendi çıkarımlarını kanıtlarla desteklemeleri gerekmektedir. Burada kanıtları karşılaştırma ve kanıtları bırakanın güvenilirliğini değerlendirme en önemli tarih araştırma aşamalarından biri olarak görülür. Öğrencilerden tarihin bir araştırma sürecinin sonucunda oluşturulduğunu ve her tarihin aslında bir yorum olduğunun farkına varmaları beklenir. Araştırmacının önceden sahip olduğu hipotezler, arşiv kaynakları ve tarihsel tartışmalar önemlidir. Sonuç olarak ölçek maddelerin hazırlanmasında kullanılan teorik yapı şu şekilde gösterilebilir:

Tablo 1. Ölçek geliştirme aşamasında yararlanılan teorik yapı

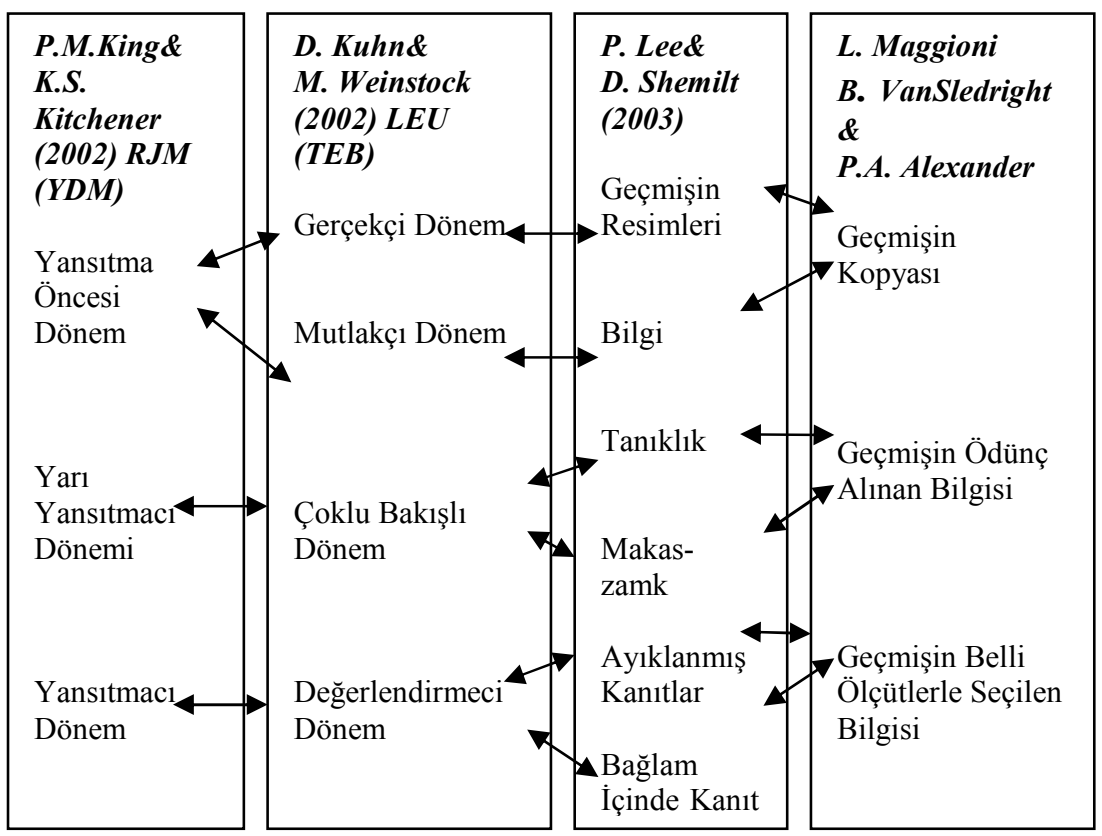




\section{YÖNTEM}

Illkögretim Öğrencilerinin Tarihsel Bilgiye Yönelik Görüşlerini Belirleme Ölçeği'nin geliştirilmesine ilişkin süreçte sırasıyla ölçek maddelerini hazırlama, kapsam geçerliği için uzman görüşü alma, deneme uygulaması adımları izlenmiştir.

\section{Ölçek maddelerinin hazırlanması}

Yukarıda anlatılan araştırmalardan elde edilen veriler 1şı̆̆ında hazırlanan maddeler yanında 6. (12) 7. (18) ve 8. (20) sinifta okumakta olan 50 ilköğretim öğrencisine

- Tarihsel bilgi değişir mi? Değişirse nasıl değişir?

- Tarihsel bilginin kaynağı nedir?

- Tarihsel bilginin sinırları nelerdir?

- Tarihçiler tarihi nasıl araştırırlar?

- Tarihsel bilginin doğruluğunu neler etkiler?

soruları yöneltilmiştir. Maddeler hazırlanırken öğrencilerin yazılı cevaplarının dışında tarihe yönelik bazı sorulara cevap vermeleri de istenmiştir. Böylece öğrencilerin tarihsel bilgiyi üreten tarihçiler ve tarihsel bilginin oluşturulma sürecine ilişkin görüşleri derinlemesine anlaşılmaya çalışılmıştır. Ardından 9 ilköğretim öğrencisi (3 altıncı sınıf, 3 yedinci sınıf ve 3 sekizinci sinıf) ile yazdıkları kullanılarak derinlemesine yapılandırılmamış görüşmeler yapılmıştır. Tüm bu çalışmalardan sonra deneme uygulamaları 19'u olumsuz olan toplam 40 madde hazırlanmıştır.

Örnek taslak maddeleri:

- Eğer bir şeyi tarih kitabından okursam bu onun doğru olduğunu gösterir.

- Sadece tarihçiler tarihte gerçekten neler olduğunu bilebilir.

- Tarih sorularına verilebilecek her zaman tek bir doğru yanıt vardır.

- Tarih ve geçmiş benim için aynı anlama sahiptir.

- Bir tarihsel olayla ilgili birden fazla açıklama olması sadece yorum farkıdır.

Hazırlanan taslak ölçeğin maddeleri, 5'li likert tipinde, "kesinlikle katılıyorum"dan (1) "kesinlikle katılmıyorum"a (5) uzanan bir yanıt aralığ1 düşünülerek oluşturulmuştur. Ölçek maddeleri hazırlanırken kullanılan dilin basit, sade ve anlaşılır olmasına özen gösterilmiştir. Ölçek maddeleri hazırlandıktan sonra önermelerin dilbilgisine uygunluğu ve açıklı gibi yönlerden net ve tek bir anlam taşımalarını kontrol açısından Türkçe dil eğitimi uzmanından görüş alınmıştır. Ayrıca 15 ilköğretim öğrencisine ölçek maddeleri okutularak anlamadıkları bir madde olup olmadığı sorulmuştur. 


\section{Kapsam Geçerliği}

Ölçeğin ölçme amacina uygunluğu ve ölçülmek istenen amac1 temsil edebilirliğini sınamak için kapsam geçerliği çalışması gereklidir (Şencan, 2005). Ölçeğin kapsam geçerliğini sağlamak üzere uzmanlardan görüş alınmıştır. Bunun için sosyal bilgiler eğitimi alanında uzman bir öğretim üyesi, tarih eğitimi alanında uzman iki öğretim üyesi, tarih alanında uzman iki tarihçi, eğitim felsefesi alanında uzman bir öğretim üyesi, sosyal bilgiler eğitimi alanında uzman bir öğretmenin, ölçekteki maddeler ve ölçeğin ölçmek istediği konuya uygunluğu konularında görüşleri alınmıştır. Uzmanlar ölçek maddelerini uygun/uygun değil/kalabilir şeklinde kodlamışlardır. Uzmanlardan gelen değerlendirmeler Cohan Kappa formülü kullanılarak hesaplanmış, buna göre uyuşum 85 olarak bulunmuştur. $\mathrm{Bu}$, hakemler arasında uyuşumun yüksek olduğunu gösteren bir değerdir çünkü 60'ın üzerindeki sonuçlar uzmanlar arasındaki uyuşmada iyi olarak değerlendirilmektedir (Şencan, 2005:758). Değerlendirme sonucunda ölçekteki bazı maddeler çıkarılmış, bazılarında da gerekli düzeltmeler yapılarak ölçek son deneme taslağ 1 haline getirilmiştir. Deneme uygulaması yapılacak olan ölçeğin toplam madde sayısı 40 'tır.

\section{Deneme Uygulamasi}

Ölçeğin geliştirme çalışması, İzmir ili Buca ilçesinin faklı sosyoekonomik bölgelerinden tabakalı örneklem yoluyla belirlenen 6 ilköğretim okulunda 6., 7. ve 8. siniflarda öğrenim görmekte olan toplam 525 öğrenciden elde edilen veriler ile yapılmıştır.

Tablo 2. Ölçeğin deneme uygulaması örneklem özellikleri cinsiyet ( $n=$ sayı)

\begin{tabular}{ll}
\hline Sinif & Toplam \\
\hline 6. sinif & 101 \\
7. sinıf & 171 \\
8. sinif & 228 \\
n & 500 \\
Kizlar & 251 \\
Erkekler & 249 \\
\hline
\end{tabular}

Alanyazın incelendiğinde örneklem büyüklüğü olarak $n=300$ rakamı iyi; $n=500$ rakamının ise çok iyi olarak (Şencan, 2005:362) değerlendirildiği görülmektedir. $\mathrm{Bu}$ yüzden deneme uygulama için 525 öğrenciden alınan verilerinin yeterli olduğu düşünülmüştür. Ölçeği özensiz dolduran ve hatalı işaretlemeler yapan toplam 25 öğrencinin verileri kapsamın dışında tutulmuştur. Ölçeğin yapı geçerlik ve güvenilirlik çalışmaları 500 
öğrenciden elde edilen verilerle yapılmıştır. Örnekleme ilişkin bilgiler Tablo 2 'de sunulmuştur.

\section{BULGULAR VE YORUM}

Deneme uygulaması sonucunda elde edilen veriler 1şı̆̆ında, bulgular kısmında Araştırmanın öncelikle yapı geçerliliği çalışmasına ilişkin bulgulara yer verilecek, daha sonra da ölçeğin güvenilirliği ile ilgili yapılan analiz sonuçları sunulacaktır.

\section{Yapı Geçerliliğinin Belirlenmesi}

Bir ölçeğin yapı geçerliği, ölçülen yapının birbiriyle yüksek korelasyon gösteren özelliklerinin birer faktör altında kümelenmesi (faktör analizi) ve ölçülen yapının homojen olduğu varsayımının sınanması (iç tutarlılık) ile belirlenebilir (Erkuş, 2003; Tavşanc1l, 2002). Tarihsel bilgiye yönelik görüşlerin hangi alt yapılardan oluştuğunu belirlemek için yapı geçerliğini sağlamak üzere betimleyici faktör analizi kullanılmıştır. Betimleyici faktör analizi, bilinmeyen bir kuramsal yapının nasıl olduğunu açıklama amacına yönelik olarak kullanılır (Erkuş, 2003:90). Bu yolla ölçüm aracıyla toplanan verilerin hangi faktörleri veya bileşenleri içerdiğine ilişkin bulgular elde edilebilir (Şencan, 2005:355). Faktör analizi öncesinde KMO ve Barlett testleri yapılmıştır. KMO değeri 0.829 ve Barlett testinin de anlamlı olduğu $\left(\mathrm{X}^{2}=1981 ; \mathrm{p}=0.00\right)$ görülmüştür. KMO ve Barlett testi sonuçlar1, verilerin faktör analizi için uygun olduğunu göstermektedir.

Başlangıçta 40 maddeden oluşan ölçek maddelerinin 13 faktörde toplandığı görülmüştür. Bu yüzden faktör yükü değerinin yüksek olmasına (0.45 ve üstü) ve binişiklik olup olmamasına dikkat edilmiş ve bu özelliklere uymayan 4 adet madde ölçekten ayıklanmıştır (Büyüköztürk, 2003). Geriye kalan maddeler faktör yük değerleri 0,40 sınır değer olarak kabul edilerek (Büyüköztürk, 2003) toplam dokuz faktörde 27 maddenin yer aldığı görülmüştür. 36 madde ile yeniden faktör analizi yapılmış ve 9 maddenin Temel Bileşenler Analizinde, 6 maddenin de Döndürülmüş Bileşenler Analizinde yük değerlerinin binişik (birden fazla faktörde yer aldığı) olduğu görülerek ölçekten çıkarılmasına karar verilmiştir. Son haliyle 21 maddeden oluşan ölçekteki maddelerin faktörlere göre dağılımları, faktör ortak varyansları, Temel Bileşenler Analizi (PCA) ve döndürme sonrası yük değerleri Tablo 3'te sunulmuştur 
Tablo 3. Faktör analizi (döndürülmüş temel bileşenler analizi) sonuçları

\begin{tabular}{llll}
\hline & & \multicolumn{2}{c}{ Yük Değeri Döndürme } \\
Madde No & $\begin{array}{l}h^{2} \text { Faktör Ortak } \\
\text { Varyans1 }\end{array}$ & $\begin{array}{l}\text { 1. Faktör } \\
\text { Yükü (PCA) }\end{array}$ & Sonraki Yük Değeri \\
\hline 7 & .648 & .589 & .699 \\
17 & .571 & .616 & .622 \\
16 & .639 & .395 & .615 \\
18 & .555 & .577 & .543 \\
15 & .529 & .489 & .453 \\
6 & .490 & .501 & .693 \\
1 & .586 & .462 & .676 \\
5 & .568 & .573 & .626 \\
2 & .518 & .449 & .505 \\
29 & .556 & .558 & .687 \\
25 & .606 & .541 & .630 \\
24 & .648 & .521 & .589 \\
27 & .529 & .457 & .556 \\
34 & .610 & .494 & .646 \\
40 & .541 & .574 & .628 \\
33 & .495 & .429 & .566 \\
39 & .510 & .462 & .528 \\
37 & .583 & .540 & .712 \\
35 & .630 & .509 & .706 \\
32 & .526 & .541 & .700 \\
21 & .481 & .545 & .540 \\
\hline
\end{tabular}

Açılanan Varyans Toplam: \% 46,871

Faktör-1: \% 19,519

Faktör-2: \% 11,266

Faktör-3: \% 5,973

Faktör-4: \% 5,28

Faktör-5: \% 4,832

Analiz sonunda, elde edilen Tarihsel Bilgiye Yönelik Görüş Ölçeğinin beş faktörlü olduğu görülmüştür. Birinci faktör, ölçeğe ilişkin toplam varyansın \% 19'unu, ikinci faktör \% 11'ini, üçüncü faktör yaklaşık \% 16 'sın1, dördüncü faktör \% 5'ini, beşinci faktör \% 4'ünü açıklamaktadır. Beş faktörün birlikte açıkladıkları toplam varyans \% 46,871'tür. Beş faktörün maddelerde açıkladıkları ortak varyans yaklaşık \% 11-38 arasında değişmektedir.

Faktör döndürme sonrasında, birinci faktörün 5 maddeden $(7,17,16,18,15)$, ikinci faktörün 4 maddeden $(6,1,5,2)$, üçüncü faktörün 4 maddeden $(29,25,24,27)$, dördüncü faktörün 4 maddeden $(34,40,33,39)$ ve beşinci faktörün 4 maddeden $(37,35,32,21)$ oluştuğu belirlenmiştir. Birinci faktördeki yük değerleri .453 ile .699 , ikinci faktördeki yük değerleri .505 ile .693, üçüncü faktördeki yük değerleri .556 ile .687, dördüncü faktörün 
yük değerleri 528 ile .646 , beşinci faktörün yük değerleri ise .540 ile 712 arasında değişmektedir. Faktörlere maddelerin içerikleri dikkate alınarak isim verilmeye çalışılmıştır. Her faktörde yer alan maddeler ve faktörlere verilen isimler Tablo 4'te sunulmuştur:

Tablo 4. Ölçek alt faktörleri ve ilgili maddeleri

\begin{tabular}{|c|c|}
\hline FAKTÖRLER & MADDELER \\
\hline $\begin{array}{l}\text { Tarihsel } \\
\text { Bilginin } \\
\text { Kesinliği }\end{array}$ & $\begin{array}{l}\text { 7- Sadece tarihçiler tarihte gerçekten neler olduğunu bilebilir. } \\
\text { 17- Bir tarihçinin tarih araştırması sonucunda elde ettiği bilgiler tek doğru } \\
\text { cevaplardır. } \\
\text { 16- Tarih hakkında merak edilen her sorunun cevabı bugüne kadar } \\
\text { bulunmuştur. } \\
\text { 18- Tarihçiler tarihte neyin doğru olduğu konusunda her zaman aynı } \\
\text { fikirdedir. } \\
\text { 15- Tarih araştırması yapmanın tek amacı doğru cevaplara ulaşmaktır. }\end{array}$ \\
\hline $\begin{array}{l}\text { Tarihsel } \\
\text { Bilginin } \\
\text { Kaynağı }\end{array}$ & $\begin{array}{l}\text { 6- Eğer bir şeyi tarih kitabından okursam bu onun doğru olduğunu gösterir. } \\
\text { 1- Ders kitabında tarih hakkında anlatılan her şey doğrudur. } \\
\text { 5- Sosyal bilgiler öğretmeninin tarih hakkında derste söylediği her şey } \\
\text { doğrudur. } \\
\text { 2- Tarih dersinde bazı konuları anlayamazsam öğretmen ne söylüyorsa onu } \\
\text { kabul etmek en doğrusudur. }\end{array}$ \\
\hline $\begin{array}{l}\text { Tarihsel } \\
\text { Bilginin } \\
\text { Gelişimi }\end{array}$ & $\begin{array}{l}\text { 29- Tarihçiler tarihsel olaylarla ilgili yeni kanıtlara ulaştıklarında tarihsel } \\
\text { bilgiler değişebilir. } \\
\text { 25- Tarihçilerin cevabını bulamadıkları bazı tarih soruları da vardır. } \\
\text { 24- Tarih kitaplarındaki bilgiler kimi zaman değişebilir. } \\
\text { 27- Tarih araştırmalarıyla elde edilen yeni bilgiler o güne kadar tarihçilerin } \\
\text { doğru olduğuna inandıkları düşüncelerin değişmesine sebep olabilir. }\end{array}$ \\
\hline $\begin{array}{c}\text { Tarihsel } \\
\text { Bilginin } \\
\text { Dayanağ1 }\end{array}$ & $\begin{array}{l}\text { 34- Tarihte doğru cevaba ulaşabilmek için tarihçilerin kullandıkları } \\
\text { yöntemler farklıdır. } \\
\text { 40- Tarihçilerin açıklamalarını tarihsel kanıtlarla ispatlamaları gerekir. } \\
\text { 33- Bir tarihsel olayla ilgili birden fazla açıklama olması sadece yorum } \\
\text { farkıdır. } \\
\text { 39- Tarihçiler farklı tarihsel kanıtları karşılaştırarak tarihsel bilgiye } \\
\text { ulaşıllar. }\end{array}$ \\
\hline $\begin{array}{l}\text { Tarihsel } \\
\text { Bilginin } \\
\text { Aktarımı }\end{array}$ & $\begin{array}{l}\text { 37- Tarihçiler tarih hakkında söylediklerinin kanıtlara dayandırmak } \\
\text { zorunda değildir. } \\
\text { 35- Aynı tarihsel olayla ilgili farklı tarihçilerin yazdıklarını okumak zaman } \\
\text { kaybıdır. } \\
\text { 32- Tarihçiler tarihi tarih kitaplarında yazan bilgileri ezberleyerek öğrenir. } \\
\text { 21- Tarihçilerin tarihsel olayları tekrar tekrar araştırmaları zaman kaybıdır. } \\
\text { 10-Tarihte bir şeyi iyi öğrenmenin en etkili yolu onu ezberlemektir. }\end{array}$ \\
\hline
\end{tabular}

Elde edilen ölçme aracının maddeleri ile alt boyut toplam puanları arasındaki ilişkinin anlamlı olup olmadığını görmek ve ölçeğin iç tutarlığını ölçmek üzere maddeler ve alt boyut, toplam puanlar temel alınarak madde toplam korelasyonu hesaplanmıştır. Ayrıca ölçeğin değerlendirilmesinde kullanılmak üzere alt boyutlardan ve ölçeğin tamamından alınabilecek en 
düşük ve en yüksek puanlar hesaplanmıştır. Elde edilen sonuçlar Tablo 5 'te sunulmuştur.

Tablo 5. Madde ve test istatistikleri ile betimsel istatistikler

\begin{tabular}{|c|c|c|c|}
\hline Madde No & $\begin{array}{l}\text { Madde-Test } \\
\text { Korelasyon } \\
\end{array}$ & Ortalama & $\begin{array}{l}\text { Standart } \\
\text { Sapma }\end{array}$ \\
\hline 7 & $0,488 * *$ & 3.24 & 1,36 \\
\hline 17 & $0,501 * *$ & 3.09 & 1.28 \\
\hline 16 & $0,439 * *$ & 3.18 & 1.92 \\
\hline 18 & $0,558 * *$ & 3.15 & 1.30 \\
\hline 15 & $0,378 * *$ & 2.50 & 1.38 \\
\hline 1. Faktör & $0,728 * *$ & 15.17 & 4.67 \\
\hline 6 & $0,393 * *$ & 2.59 & 1.18 \\
\hline 1 & $0,200 * *$ & 2.47 & 1.16 \\
\hline 5 & $0,409 * *$ & 2.42 & 1.22 \\
\hline 2 & $0,374 * *$ & 2.89 & 1.38 \\
\hline 2. Faktör & $0,511 * *$ & 10.38 & 3.36 \\
\hline 29 & $0,256 * *$ & 3.60 & 1.14 \\
\hline 25 & $0,266^{*}$ & 3.93 & 1.13 \\
\hline 24 & $0,112 * *$ & 3.43 & 1.21 \\
\hline 27 & $0,163 * *$ & 3.50 & 1.10 \\
\hline 3. Faktör & $0,302 * *$ & 14.48 & 3.01 \\
\hline 34 & $0,182 * *$ & 3.51 & 1.14 \\
\hline 40 & $0.256 * *$ & 3.88 & 1.24 \\
\hline 33 & 0,009 & 3.53 & 1.17 \\
\hline 39 & $0,133^{* *}$ & 3.74 & 1.07 \\
\hline 4. Faktör & $0,219 * *$ & 14.67 & 3.09 \\
\hline 37 & $0,559 * *$ & 3.11 & 1.34 \\
\hline 35 & $0,507 * *$ & 3.30 & 1.45 \\
\hline 32 & $0,499 * *$ & 3.23 & 1.41 \\
\hline 21 & $0,511 * *$ & 3.33 & 1.52 \\
\hline 5. Faktör & $0,718 * *$ & 12.98 & 4.14 \\
\hline Toplam & 1 & 67.70 & 9.69 \\
\hline
\end{tabular}

* Korelasyon 0.01 seviyesinde çift yönlü olarak anlamlı bulunmuştur.

Tablo 5'te görüldüğü gibi ölçek ile ölçüt alınan tarihsel bilgiye yönelik görüş puanları arasındaki hesaplanan korelasyon 1. faktör için 0.728 $(\mathrm{p}<0.01), 2$ faktör için $0.511(\mathrm{p}<0.01), 3$. faktör için $0.302(\mathrm{p}<0.01), 4$. faktör için $0.219 \quad(\mathrm{p}<0.01)$, 5. faktör için $0.718 \quad(\mathrm{p}<0.01)$ olarak bulunmuştur. Hem madde hem de faktör temelinde elde edilen madde-test korelasyon katsayıları negatif, sıfır ya da sıfıra yakın bulunmuştur; dolayısıyla aracın iç tutarlılığının yüksek ve yapı geçerliğinin var olduğu söylenebilir (Tavşancıl, 2002:54).

Elde edilen ölçeğin son halinin 21 maddeden oluştuğu, ölçeğin 5'li likert tipinde hazırlandığ 1 ve puanların postmodern tarihsel bilgi anlayışı 
göz önünde bulundurularak tek yönlü kodlandığını göz önünde bulundurulursa, ölçekten toplam ve alınabilecek en yüksek puan 80 , en düşük puan ise 16 'dır. Puanlar hesaplanırken, geleneksel tarihsel bilgi anlayışını yansıtan ve tamamı 1 . faktörde yer alan maddelere ait puanlar ters kodlanmıştır. Ayrıca her faktörden alınabilecek en yüksek puanlar sırasıyla $40,25,15$ ve en düşük puanlar da 8,5 ve 3 olarak hesaplanmıştır.

Ölçekteki madde puanlarının standart sapması incelendiğinde, maddelerin standart sapmalarının 0.96 ile 1.34 arasında değişen değerlere sahip olduğu görülmüştür. Ayrıca faktör ve toplam puan ortalamalarının standart sapmalarının da 3.45 ila 5.98 arasında değiştiği görülmektedir. $\mathrm{Bu}$ durumda, grubun dağılım ölçüsünün küçük (grubun benzeşik), dolayısıyla geliştirilen ölçeğin madde, faktör temellendirme ve toplamda hitap ettiği grupla ilgili olarak güvenilir olduğu söylenebilir.

$\mathrm{Bu}$ araştırmada açımlayıcı faktör analizinden sonra bir de hazırlanan bu modeli denemek üzere doğrulayıcı faktör analizi yapılmıştır. Açımlayıcı faktör analizi araştırmacıya maddelerinin hangi faktörler altında yüklendiğinin incelemesine olanak verirken (Coakes, 2005:154) doğrulayıc1 faktör analizi ise araştırmacının oluşturduğu modelin veri tarafından doğrulanma sürecini incelemeye yöneliktir (Noar, 2003). Araştırmacıların çoğu, ölçek geliştirme çalışmalarında açımlayıcı faktör analizinin sonrasında doğrulayıcı faktör analizi kullanma eğilimindedir (Worthington ve Whittaker, 2006:5).

Doğrulayıcı faktör analiziyle belirlenen beş faktörün araştırma verisi tarafindan doğrulanma oranı doğrulayıcı faktör analiziyle incelemiştir. Yapı geçerliğinin bu aşamasında ilköğretim öğrencilerinin tarihsel görüşlerini belirleme ölçeğine ilişkin oluşturulan ikinci düzey (high order) model, doğrulayıcı faktör analizi kullanılarak sınanmıştır. İkinci düzey doğrulayıcı faktör analizi sonucunda modifikasyon önerileri incelendiğinde Madde 5 Madde 18 arasındaki ilişkilerin modelin uyum iyiliği indekslerini önemli oranda düşürdüğü görüldüğünden ölçekten çıkarılmıştır.

Model uyumuna ilişkin ilk inceleme ki kare katsayısının serbestlik derecesine oranı aracılığıyla incelenmiştir. Bu oranın 5'ten küçük olmas1 modelin kabul edilebilir olduğunu göstermektedir (Şimşek, 2007:14). Bu araştırmada uyum iyilik indeksleri olarak kare uyum indeksi (Relative Fit Index, RFI), orant1l1 uyum indeksi (Comparative Fit Index, CFI), ortalama hataların karekökü (Root Mean Square Residuls, RMR), farklılık uyum indeksi (Incremental Fit Index, IFI) ve yaklaşık hataların ortalama karekökü (Root Mean Square Error of Approximation, RMSEA) indeksleri kullanılmıştır. Araştırmacılar GFI, NFI, RFI, CFI ve IFI indekslerine ilişkin değerlerin .90 'dan büyük RMSEA değerinin ise .80 'den küçük olmasının yeterli olduğunu belirtmektedir (Şimşek, 2007). Tablo 6'ya bakıldığında 
modele ilişkin tüm uyum iyiliği indekslerinin yeterlilik gösterdiği görülmektedir.

Tablo 6. DFA modelinin uyum iyiliği indeksleri

\begin{tabular}{lllllllll}
\hline$\chi^{2}$ & sd & $\chi^{2} / \mathbf{s d}$ & GFI & NFI & RFI & CFI & RMR & RMSEA \\
411,22 & 159 & 2,59 & 0,92 & 0,92 & 0,91 & 0,90 & 0,05 & 0,05 \\
\hline
\end{tabular}

Modele ilişkin uyum iyiliğgi indekslerinin yeterlilik gösterdiği dikkate alınarak araştırmanın nihai modeli olarak Tablo 7'de yer alan modele göre analiz sonlandırılmıştır.

Tablo 7. DFA modeline ilişkin son analiz sonuçlart

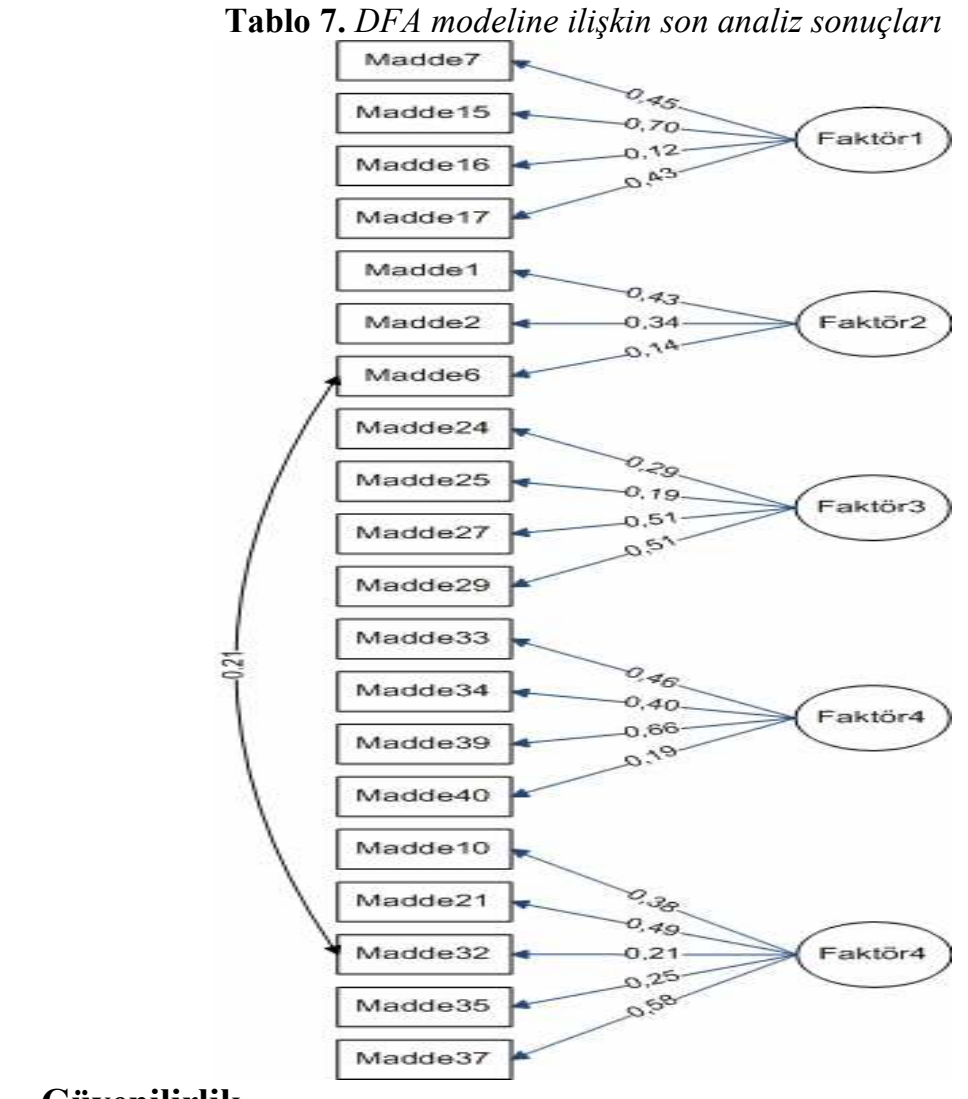

\section{Güvenilirlik}

Geçerli bir ölçek aynı zamanda güvenilir bir ölçektir (Fraenkel ve diğ. 1996). Güvenilirlik, ölçme aracının ölçtügü özellikleri ne derece tutarlı ve hatalardan arınık ölçtüğünün göstergesidir. Yapı geçerliğini test etmek üzere uygulanan açımlayıcı faktör analizi sonucu belirlenen 21 madde ve beş 
faktörden oluşan ölçeğin alt faktörlerinin ve tamamının güvenirliği Cronbach $\alpha$ katsayısı elde edilmiş ve Tablo 5'te sunulmuştur. Ayrıca ölçeğin kararlılığını ortaya koymak üzere farklı bir örneklem grubuna İzmir ili Buca ilçesinde bir ilköğretim okulunun 6., 7. ve 8. sınıflarında öğrenim gören toplam 120 öğrenciye - 4 hafta ara ile (Büyüköztürk, 2003) ölçek yeniden uygulanmış ve elde edilen puanlar arasındaki ilişki incelenmiştir. Elde edilen sonuçlar Tablo 8'de sunulmuştur.

Tablo 8. Ölçek alt faktörlerinin cronbach $\alpha$ değerleri

\begin{tabular}{llllllll}
\hline & $\mathrm{n}$ & 1. & 2. & 3. & 4. & 5. & Toplam \\
& & Faktör & Faktör & Faktör & Faktör & Faktör & \\
\hline Cronbach $\alpha$ & 500 & 0,72 & 0,51 & 0,30 & 0,21 & 0,71 & 0,82 \\
$\begin{array}{l}\text { Test-Tekrar-Test } \\
\text { Güvenilirliği }\end{array}$ & 120 & 0,81 & 0,83 & 0,79 & 0,86 & 0,82 & 0,83 \\
\hline
\end{tabular}

$\mathrm{Bu}$ sonuçlara göre ölçeğin güvenilir sayllabilmesi için güvenirlik katsayısının 0.70 ve daha yüksek olması gerektiği (Tavşancıl, 2002; Büyüköztürk, 2003) dikkate alındığında, ölçeğin tamamının $(\alpha=0.83)$ güvenilir olduğu görülmektedir. Ölçeğin test-tekrar test sonuçlarının ise 1 . faktör için $0.81,2$. faktör için $0.83,3$. faktör için $0.79,4$. faktör için $0.86,5$. faktör için 0.82 ve ölçeğin tamamı için 0.83 olduğu görülmektedir. Elde edilen sonuçlar doğrultusunda ölçeğin zaman içinde kararlılık gösteren bir yapıya sahip olduğu belirtilebilir.

\section{SONUÇ VE ÖNERILER}

$\mathrm{Bu}$ çalışmada, ilköğretim öğrencilerinin tarihsel bilgiye yönelik görüşlerini belirlemek üzere ölçek geliştirme süreci ele alınmıştır.

Çalışma sonunda, toplam 5 faktörden oluşan ve Cronbach $\alpha$ güvenilirlik katsayısı 0,82 bulunan 20 maddelik güvenilir bir ölçek elde edilmiştir. Çalışma sonunda, ortaya çıkan faktör yapıları incelendiğinde tarihsel bilginin epistemoloji alanına vurgu yapan ve öğrencilerin bu alandaki temel konulara ilişkin (tarihsel bilginin kesinliği, aktarımı, gelişimi, kaynağı) görüşlerini rahatlıkla ortaya koyan bir ölçek geliştirildiği anlaşılmaktadır.

Çalışma sonucunda, elde edilen ölçekte yer alan; "Sadece tarihçiler tarihte gerçekten neler olduğunu bilebilir", "Bir tarihçinin tarih araștırması sonucunda elde ettiği bilgiler tek doğru cevaplardır", "Tarih hakkında merak edilen her sonunun cevabı bugüne kadar bulunmuştur", "Tarihçiler tarihte neyin doğru olduğu konusunda her zaman aynı fikirdedir", "Tarih araştırması yapmanın tek amacı doğru cevaplara ulaşmaktır", ifadeler 
tarihsel bilginin kesinliği faktörü çatısı altında toplanmıştır. Tarihsel bilginin kaynağı faktörü altında yer alan ifadeler; "Eğer bir şeyi tarih kitabından okursam bu onun doğru olduğunu gösterir", "Ders kitabında tarih hakkında anlatılan her şey doğrudur","Sosyal bilgiler öğretmeninin tarih hakkında derste söylediği her şey doğrudur", "Tarih dersinde bazı konuları anlayamazsam öğretmen ne söylerse onu kabul etmek en doğrusudur" dur. Tarihsel bilginin gelişimi faktörü altında toplanan ifadeler ise; "Tarihçiler tarihsel olaylarla ilgili yeni kanıtlara ulaştıklarında tarihsel bilgiler değişebilir", "Tarihçilerin cevabını bulamadıkları bazı tarih soruları da vardır", "Tarih kitaplarındaki bilgiler kimi zaman değişebilir", "Tarih araştırmalarıyla elde edilen yeni bilgiler o güne kadar tarihçilerin doğru olduğuna inandıkları düşüncelerin değişmesine sebep olabilir" şeklindedir. Tarihsel bilginin kaynağı alt başlığında da "Tarihte doğru cevaba ulaşabilmek için tarihçilerin kullandıkları yöntemler farklıdır", "Tarihçilerin açıklamalarını tarihsel kanıtlarla ispatlamaları gerekir", "Bir tarihsel olayla ilgili birden fazla açıklama olması sadece yorum farkıdır", "Tarihçiler farklı tarihsel kanıtları karşılaştırarak tarihsel bilgiye ulaşırlar" ifadeleri yer almaktadır. Bu maddeler özellikle ilköğretim öğrencilerinin tarihsel bilgiye yaklaşımlarını gelen olarak değerlendirmeye yönelik veriler elde edilmesini sağlayabilecektir.

Çalışma sonunda elde edilen bu ölçek, öğrencilerin tarihsel bilgiye yönelik görüşlerini farklı değişkenler açısından (sosyo-ekonomik düzey, cinsiyet, öğrenme yaklaşımları, güdü v.b.) incelemeyi amaçlayan araştırmalarda kullanılabilir. Bunun yanında tarih öğretmenleri, sosyal bilgiler öğretmenleri ve eğitim araştırmacıları da öğrencilerin öğrenme ortamlarına getirdikleri bireysel farklıl1kları derinlemesine incelemek için yine bu ölçekten yararlanabilir. 


\section{KAYNAKLAR}

Barton, K. C. (1996). Narrative simplifications in elementary students' historical thinking. In Brophy, J (Eds.). Advances in research on teaching,: Teaching and learning in history, (pp.51-84).Greenwich, CN: JAI Press.

Breisach, E. (2009). Tarihyazımı. (Çev:H. Kocaoluk).İstanbul: Yapı Kredi Yayınları.

Büyüköztürk, Ş. (2003). Veri Analizi El Kitabı. 2. Baskı. Ankara: Pegem/A Yayıncilik.

Carr, E. H. (1996). Tarih Nedir?. (Çev: M.G.Göktürk). İstanbul: İletişim Yayınları.

Cevizci, A. (1997). Felsefe Sözlüğü. Ankara: Ekin Yayınları.

Coakes, S. J. (2005). SPSS: Analysis without anguish: Version 12.0 for Windows. Melbourne: John Wiley and Sons.

Çulha, B. (2006). “Tarihsel Mekânlarda Sosyal Bilgiler Öğretimine Yönelik Öğrenci Görüşleri”. Yayınlanmamış yüksek lisans tezi. Dokuz Eylül Üniversitesi Eğitim Bilimleri Enstitüsü, Ankara.

Dilek, D. (2002). Tarih Derslerinde Öğrenme ve Düşünce Gelişimi, Ankara: Pegem/A Yayıncilik

Dilek, D. (2009). Geçmişi İmgelerle Yeniden Kurmak: İlköğretim Düzeyinde Tarihsel İmgelem Becerilerinin Kullanımı Üzerine İkonografik Bir Analiz. Kuram ve Uygulamada Eğitim Bilimleri, 9 (2) Bahar 2009, 633-689.

Erkuş, A. (2003). Psikometri Üzerine Yazılar. Ankara:Türk Psikologlar Derneği Yayınları.

Foster, S. J. \& E. A. Yeager, (1999). "You've got put together the pieces": English 12 years olds encounter and learn from historical evidence. Journal of Curriculum and Supervision. 14 (4), 286-298.

Jenkins, K. (1997) Tarihi Yeniden Düşünmek. (Çev: B. Şener). Ankara: Dost Kitabevi Yayınları.

Kuhn, D., Weinstock, M. (2002). What is epistemological thinking and does it matter?. B. K. Hofer \& P.R. Pintrich (Eds.) Personal epistemology: The psychology of beliefs about knowledge and knowing (pp. 121-144) Mahwah, NJ: Lawrence Erlbaum Associates.

Lee, P., Shemilt, D. (2003). A scaffold, not a cage: Progression and progression models in history. Teaching History, 113, 13-24.

Lee, P., Ashby, R. (2000). Progression in historical understanding among students ages 7-14 In P. N. Stearns, P. Seixas., S. Wineburg (Eds.). Knowing, Teaching and Learning History: National and International Perspectives (pp.199-222). New York: New York University Press.

Lee, P. J. (2004). Understanding History. In P. Seixas (Eds). Theorizing Historical Consciousness (pp.129-164). Toronto: University of Toronto Press.

Levstik, L. S., Barton, K. C. (2001). Doing History: Investigating with Children in Elementary and Middle School. New York: Routledge Press.

Noar, S. M. (2003). The role of structural equation modeling in scale development. Structural Equation Modeling: A Multidisciplinary Journal, 10(4), 622-647.

Özbaran, S. (1992). Tarih ve Öğretimi. İstanbul: Cem Yayınevi. 
Özlem, D. (2005). Tarih Felsefesi. İzmir: Dokuz Eylül Üniversitesi Yayınları.

Safran, M. (2008). Türkiye'de Tarih Eğitimi ve Öğretimi. M. Safran, D. Dilek (Ed). 21. Yüzyllda Kimlik, Vatandaşllk ve Tarih (ss.7-13). İstanbul: Yeni İnsan Yayınevi.

Schommer, M. (1990). Effect of beliefs about the nature of knowledge on comprehension. Journal of Educational Psychology, 82, 498-504.

Şencan, H. (2005). Sosyal ve Davranışsal Ölçümlerde Güvenilirlik ve Geçerlilik. Ankara: Seçkin Yayınları.

Şimşek, Ö. F. (2007). Yapısal Eşitlik Modellemesine Giriş: Temel İlkeler ve LISREL Uygulamalarl. Ankara: Ekinoks Yayıncilık.

Tavşancıl, E. (2002). Tutumların Ölçülmesi ve SPSS ile Veri Analizi. Ankara: Nobel Yayınevi.

Tosh, J. (2005). Tarihin Peşinde. (Çev: Ö. Arıkan), İstanbul: Tarih Vakfı Yurt Yayınları.

VanSledright, B. (2002). In search of america's past. Learning to read history in elementary school: New York: Teacher College Press.

Wineburg, S. (1991). Historical problem solving: A study of the cognitive processes used in the evaluation of documentary and pictorial evidence: Journal of educational Psychology, 83, 73-87.

Wineburg, S. (2001). Historical thinking and other unnatural acts. Charting the future of teaching the past. Philadelphia: Temple University Press.

Worthington, R. L ve Whittaker, T.A. (2006). Scale development research: A content analysis and recommendations for be"st practives. The Counseling Psychologist, 34, 806-838.

Yapıcı, G. (2006). "Dört Kültürde Tarih Öğretimi Yaklaşımı: İngiltere, Fransa, İsviçre ve Türkiye Örnekleri”, Yayınlanmamış yüksek lisans tezi, Marmara Üniversitesi Eğitim Bilimleri Enstitüsü, İstanbul.

Yeager, E., Davis, O. L. (1996) Classroom teachers thinking about historical texts. An exploratory study. Theory and Research in Social Education. 24. 144-166. 